\title{
Peranan Ketua Pengurus dan Manajer Dalam Penyusunan dan Penerapan Laporan Keuangan Berbasis SAK ETAP Pada Koperasi di Kota Palembang
}

\author{
Riza Syahputera ${ }^{\mathbf{1}}$ dan Martha Rianty $\mathbf{N}^{\mathbf{2}}$ \\ 1-2 Jurusan Akuntansi, Universitas Tridinanti Palembang \\ Email: syahputra_riza@yahoo.com \\ Email: Rianty533@gmail.com
}

\begin{abstract}
This study aims to determine the effect of the role of the Chairperson and Cooperative Manager in the preparation and application of Financial Statements based on SAK ETAP in cooperatives in the city of Palembang. This research is a quantitative study using data obtained from questionnaires and measured using a Likert scale. The sampling technique used is purposive sampling. The sample used in this study was the Chairperson of the cooperative and the manager of the cooperative in the city of Palembang. The cooperatives studied were 203 cooperatives. The data analysis technique used is multiple linear regression test. The results showed that the role of cooperative leaders and managers had a significant positive effect on the preparation and application of SAK ETAP-based financial statements.
\end{abstract}

Keywords : chairman, manager, SAK ETAP, cooperative

\begin{abstract}
Abstrak
Penelitian ini bertujuan untuk mengetahui pengaruh peranan Ketua dan Manajer Koperasi dalam penyusunan dan penerapan Laporan Keuangan berbasis SAK ETAP pada koperasi di kota Palembang. Penelitian ini merupakan penelitian kuantitatif dengan menggunakan data yang diperoleh dari kuesioner dan diukur menggunakan skala likert. Teknik sampel yang digunakan adalah purposive sampling. Sampel yang digunakan dalam penelitian ini adalah Ketua koperasi dan Manajer koperasi di Kota Palembang, Koperasi yang diteliti sebanyak 203 koperasi. Teknik analisis data yang digunakan yaitu uji regresi linier berganda. Hasil penelitian menunjukkan bahwa Peranan ketua koperasi dan manajer berpengaruh signifikan positif terhadap penyusunan dan penerapan Laporan keuangan berbasis SAK ETAP.
\end{abstract}

Kata kunci : ketua, manajer, koperasi, SAK ETAP

\section{Pendahuluan}

Pertumbuhan perekonomian suatu bangsa memerlukan pengaturan sumber-sumber ekonomi yang tersedia agar terarah dan terpadu sehingga dapat meningkatkan taraf hidup bangsa dan kesejahteraan masyarakat. Sesuai dengan pasal 33 Undang-Undang Dasar 1945, salah satu cara yang ditempuh pemerintah untuk meningkatkan kesejahteraan masyarakat adalah dengan mendirikan lembaga-lembaga perekonomian rakyat, yaitu salah satunya adalah koperasi.

Koperasi adalah badan usaha yang beranggotakan orang-orang atau badan hukum koperasi dengan melandaskan kegiatannya berdasarkan prinsip koperasi sekaligus sebagai gerakan ekonomi rakyat yang berdasarkan atas asas kekeluargaan (Departemen Koperasi: 1992). Artinya koperasi sebagai unit bisnis diberikan kesempatan utuk menjalankan usaha dalam rangka memperoleh keuntungan, namun harus tetap tidak meniggalkan karakteristik dan prinsip-prinsip koperasi yang telah ditetapkan. 
Kota Palembang merupakan salah satu kota yang sedang berkembang terutama dalam bidang koperasi. Hal ini terbukti dari jumlah koperasi yang berada di Palembang sebanyak 674 Koperasi yang tersebar di kota Palembang. Semakin pesatnya pertumbuhan koperasi di Palembang ini sehingga menimbulkan permasalahan yaitu kurangnya pengetahuan dalam penyusunan laporan keuangan koperasi sehingga koperasi memerlukan adanya staff keuangan yang mengerti tentang Standar Akuntansi Keuangan Entitas Tanpa Akuntabilitas (SAK - ETAP) yang memadai dalam proses usahanya untuk dapat dipercayai oleh masyarakat.

NIK adalah nomer induk koperasi, dimana koperasi yang sudah memiliki nomer induk koperasi merupakan koperasi yang sudah terdaftar pada Dinas Koperasi. Sedangkan untuk koperasi yang belum memiliki nomor induk belum terdaftar pada Dinas Koperasi. Pemberian nomor induk biasanya hanya

pada koperasi yang masih aktif, akan tetapi di Palembang banyak koperasi yang aktif belum memiliki nomor induk koperasi. Maka dari itu dapat disimpulkan bahwa ada koperasi yang aktif beroperasi tetapi belum memiliki nomor induk, yang berarti belum terdaftar pada Dinas Koperasi. Nomor induk berbeda dengan nomor badan hukum koperasi, dimana pengertian dari badan hukum koperasi ialah izin yang diberikan kepada pemerintah secara sah atas akta pendirian koperasi.

Karena di Kota Palembang terdapat banyak Koperasi yang belum bersertifikat NIK, maka dari itu penulis ingin meneliti koperasi tersebut. Apakah koperasi yang belum bersertifikat NIK memiliki pengaruh antara tingkat pendidikan yang dimiliki, pemahaman akuntansi koperasi berbasis SAK-ETAP.

Untuk mampu bertahan di era globalisasi tentunya koperasi harus instropeksi atas kondisi yang ada pada dirinya.. Tidak dapat dipungkiri bahwa hanya dengan mengenal jati diri koperasi secara benar maka kemungkinan bersaing dengan badan usaha lain akan terbuka. Jelas bahwa ditinjau dari sudut bentuk organisasinya, maka organisasi koperasi adalah SHO (self-helporganisasi). Intinya koperasi adalah badan usaha yang otonom. Problemnya adalah otonomi koperasi sejauh ini menjadi tanda tanya besar. Masalah mutu sumberdaya manusia pada berbagai perangkat organisiasi koperasi menjadi masalah yang menonjol dan mendapat sorotan. Subyakto (2009) mempunyai pandangan bahwa, kendala yang sangat mendasar dalam pemberdayaan koperasi dan usaha kecil adalah masalah sumberdaya manusia. Pengurus dan karyawan secara bersama-sama -ataupun saling menggantikan- menjadi pelaku organisasi yang aktif, dan menjadi front line staff dalam melayani anggota koperasi. Keadaan saling menggantikan seperti itu, banyak terjadi dalam praktik manajemen koperasi di Indonesia. Kinerja front line staff memiliki dampak terhadap kepuasan pihak-pihak yang memiliki kaitan dengan pengembangan koperasi, antara lain adalah anggota sebagai pemilik dan pemanfaat, pemerintah sebagai Pembina serta pihak mitra bisnis yang berperan sebagai pemasok, distributor, produsen, penyandang dana dan lain sebagainya.

\section{Landasan Teori Pengertian Koperasi}

Menurut Undang-undang No. 25/1992, koperasi adalah badan usaha yang beranggotakan orang-perorangan atau badan hukum Koperasi dengan melandaskan kegiatannya berdasarkan prinsip Koperasi sekaligus sebagai gerakan ekonomi rakyat yang berdasarkan asas kekeluargaan (Sitio dan Tamba, 2010). Koperasi sebagai organisasi ekonomi yang berwatak sosial sebagai usaha bersama berdasar asas-asas kekeluargaan dan gotong royong (Widiyati, 2010). Ropke menyatakan makna koperasi 
dipandang dari sudut organisasi ekonomi adalah suatu organisasi bisnis yang para pemilik/anggotanya adalah juga pelanggan utama perusahaan tersebut. Kriteria identitas koperasi akan merupakan dalil/prinsip identitas yang membedakan unit usaha koperasi dari unit usaha lainnya (Hendar dan Kusnadi, 2009). Elemen yang terkandung dalam koperasi menurut International Labour Organization (Sitio dan Tamba, 2010) adalah:

a. perkumpulan orang-orang,

b. penggabungan orang-orang tersebut berdasarkan kesukarelaan,

c. terdapat tujuan ekonomi yang ingin dicapai,

d. koperasi yang dibentuk adalah suatu organisasi bisnis (badan usaha) yang diawasi dan dikendalikan secara demokratis,

e. terdapat kontribusi yang adil terhadap modal yang dibutuhkan,

f. anggota koperasi menerima resiko dan manfaat secara seimbang.

\section{Manajemen Koperasi}

Koperasi merupakan lembaga yang harus dikelola sebagaimana layaknya lembaga bisnis. Di dalam sebuah lembaga bisnis diperlukan sebuah pengelolaan yang efektif dan efisien yang dikenal dengan manajemen. Demikian juga dalam badan usaha koperasi, manajemen merupakan satu hak yang harus ada demi terwujudnya tujuanyang diharapkan. Prof. Ewell Paul Roy mengatakan bahwa manajemen koperasi melibatkan 4 (empat) unsur yaitu: anggota, pengurus, manajer, dan karyawan. Seorang manajer harus bisa menciptakan kondisi yang mendorong para karyawan agar mempertahankan produktivitas yang tinggi. Karyawan merupakan penghubung antara manajemen dan anggota pelanggan (Hendrojogi, 2009).

Menurut Suharsono Sagir, sistem manajemen di lembaga koperasi harus mengarah kepada manajemen partisipatif yang di dalamnya terdapat kebersamaan, keterbukaan, sehingga setiap anggota koperasi baik yang turut dalam pengelolaan (kepengurusan usaha) ataupun yang di luar kepengurusan (angota biasa), memiliki rasa tanggung jawab bersama dalam organisasi koperasi (Anoraga dan Widiyanti,2010).

Unsur Pengawas seperti yang terdapat pada alat perlengkapan organisasi koperasi, pada hakekatnya adalah merupakan perpanjangan tangan dan anggota, untuk mendampingi Pengurus dalam melakukan fungsi kontrol sehari-hari terhadap jalannya roda organisasi dan usaha koperasi. Keberhasilan koperasi tergantung pada kerjasama ketiga unsur organisasi tersebut dalam mengembangkan organisasi dan usaha koperasi, yang dapat memberikan pelayanan sebaik-baiknya kepada anggota. Dan sudut pandang proses, manajemen koperasi lebih mengutamakan demokrasi dalam pengambilan keputusan. Istilah satu orang satu suara (one man one vote) sudah mendarah daging dalam organisasi koperasi. Karena itu, manajemen koperasi ini sering dipandang kurang efisien, kurang efektif, dan sangat mahal. Terakhir, ditinjau dan sudut pandang gaya manajemen (management style), manajemen koperasi menganut gaya partisipatif (participation management), di mana posisi anggota ditempatkan sebagai subjek dan manajemen yang aktif dalam mengendalikan manajemen perusahaannya. Sitio dan Tamba (2010) menyatakan badan usaha koperasi di Indonesia memiliki manajemen koperasi yang dirunut berdasarkan perangkat organisasi koperasi, yaitu: Rapat anggota, pengurus, pengawas, dan pengelola. Telah diuraikan sebelumnya bahwa, watak manajemen koperasi ialah gaya manajemen partisipatif. Pola umum manajemen koperasi yang partisipatif tersebut menggambarkan adanya interaksi antar unsur manajemen koperasi. Terdapat 
pembagian tugas (job description) pada masing-masing unsur. Demikian pula setiap unsur manajemen mempunyai lingkup keputusan(decision area) yang berbeda, kendatipun masih ada lingkup keputusan yang dilakukan secara bersama (shared decision areas)

\section{Pemahaman Akuntansi Koperasi Berbasis SAK-ETAP}

SAK-ETAP digunakan oleh entitas yang tidak memiliki akuntabilitas public yang signifikan, seperti koperasi, Bank Perkreditan Rakyat (BPR), UMKM dan lain sebagainya. SAK-ETAP disahkan DSAK-IAI pada tanggal 19 mei 2009. SAK-ETAP diterapkan untuk penyusunan laporan keuangan yang dimulai pada atau setelah 1 januari 2011. Akuntansi perkoperasian di Indonesia telah mengalami perkembangan seiring konvergensi IFRS, sebelumya akuntansi koperasi diatur dalam PSAK No.27. Namun, sejak 08 April 2011 DSAK IAI telah menerbitan pernyataan pencabutan SAK 8 (PPSAK 8) atas pencabutan PSAK No.27 tentang akuntansi koperasi, dan sebagai gantinya Pemerintah RI telah menerbitkan peraturan Menteri Negara KUKM RI KUKM Nomor: 04/PER/M.KIKM/VII/2012 tertanggal 26 Juli 2012 tentang pedoman Umum Akuntansi Koperasi Berbasis SAK-ETAP.

Pedoman umum akuntansi koperasi sebagaimana tersebut dalam Peraturan Menteri Negara KUKM RI KUKM Nomor: 04/PER/M.KUKM/VII/2012 secara garis besar membahas mengenai karakteristik koperasi, kerangka dasar laporan keuangan koperasi, akuntansi asset, akuntansi kewajiban, akuntansi ekuitas, perhitugan hasil usaha, laporan arus kas, laporan perubahan ekuitas dan catatan atas laporan keuangan . Dengan memahami isi dari peraturan Menteri ini, diindikaskan pegawai mampu menyusun laporan koperasi yang terbatas dadi praktik manajemen laba, tidak menyajikan laporan keuangan koperasi yang salah,tidak menyembunyikan informasi penting dan material dalam laporan keuangan koperasi dan memliki orientasi tanggung jawab kepada pengurus/atasan bukan kepada pemilik koperasi/RAT.

\section{Kerangka Penelitian}

Gambar 1 yang menyajikan Kerangka Pemikiran penelitian ini sebagai berikut:

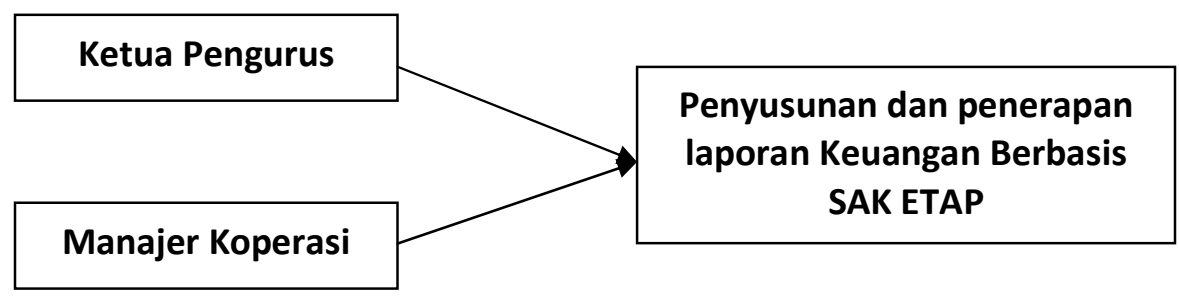

Gambar 1. Kerangka Penelitian

\section{Hipotesis Penelitian}

H1 : Peranan Ketua Pengurus dan Manajer berpengaruh Dalam Penyusunan dan Penerapan Laporan Keuangan Berbasis SAK ETAP Pada Koperasi di Kota Palembang

\section{Metode Penelitian}

Jenis penelitian ini adalah Asosiatif yaitu penelitian yang bertujuan untuk mencari tahu Peranan Ketua Pengurus dan Manajer dalam Penyusunan dan Penerapan 
Laporan Keuangan Berbasis SAK ETAP Pada Koperasi Di Kota Palembang. Populasi dalam penelitian ini adalah Ketua Pengurus dan Manajer yang bekerja pada Koperasi yang ada di kota palembang tahun 2018. Adapun responden dalam penelitian ini sebanyak 250 Koperasi yang aktif sebanyak 203 Koperasi.

Instrumen penelitian yang digunakan dalam penelitian ini adalah kuesioner, yang berisi mengenai pertanyaan dan pernyataan yang akan dijawab responden. Skala yang digunakan adalah Skala Likert (Likert Scale) didesain untuk menelaah seberapa kuat subjek setuju atau tidak setuju dengan pernyataan pada skala 4 titik dengan susunan.

\begin{tabular}{ccccc}
\hline $\begin{array}{c}\text { Sangat Tidak } \\
\text { Setuju }\end{array}$ & Tidak & Netral & Setuju & $\begin{array}{c}\text { Sangat } \\
\text { Setuju }\end{array}$ \\
$\mathbf{1}$ & $\mathbf{S e t u j u}$ & & & $\mathbf{5}$ \\
\hline
\end{tabular}

Respons terhadap sejumlah item yang berkaitan dengan konsep atau variabel tertentu kemudian disajikan kepada tiap responden. Ini adalah skala interval (interval scale) dan perbedaan dalam respons antara dua titik pada skala tetap sama. (Sekaran, 2011:31)

Uji regresi digunakan untuk meramalkan suatu variabel (variabel dependent) bedasarkan satu variabel atau beberapa variabel lain (variabel independent) dalam suatu persamaan linear, yaitu: $Y=a+b_{1} X_{1}+b_{2} X_{2} \ldots+b_{n} X_{n}$ persamaan linear dengan beberapa variabel independent. (Trihendradi C, 2013:155). Teknik analisis datanya menggunakan model regresi linear berganda (multiple linear regression). Model yang digunakan adalah sebagai berikut:

$$
Y_{1 t}=a+b_{1} X_{1}+b_{2} X_{2}+e_{1 t}
$$

Keterangan :

$Y_{1 t} \quad=$ Laporan Keuangan Berbasis SAK ETAP

$X_{1} \quad=$ Peran Ketua Pengurus

$X_{2} \quad=$ Peran Manager

$a, b_{1}, b_{2} \quad=$ Konstanta

$e_{1 t} \quad=$ error

\section{Hasil dan Pembahasan Uji Validitas}

Pengujian ini dilakukan untuk menguji kesahihan setiap item pernyataan dalam mengukur variabelnya. Teknik korelasi yang digunakan untuk menguji validitas butir pernyataan dalam penelitian ini adalah Pearson Product Moment. Apabila nilai koefisien korelasi butir item pernyataan yang sedang diuji lebih besar dari r-kritis sebesar 0,3 maka dapat disimpulkan bahwa item pernyataan tersebut merupakan konstruksi (construct) yang valid. Adapun hasil uji validitas kuesioner untuk variabel yang diteliti disajikan pada tabel berikut : 


\begin{tabular}{|c|c|c|c|c|}
\hline Dimensi & Butir Pernyataan & R hitung & R Kritis & Keterangan \\
\hline & Pernyataan 1 & 1.000 & 0,3 & Valid \\
\hline & Pernyataan 2 & .634 & 0,3 & Valid \\
\hline & Pernyataan 3 & .637 & 0,3 & Valid \\
\hline Ketua Pengurus & Pernyataan 4 & .882 & 0,3 & Valid \\
\hline (X1) & Pernyataan 5 & .637 & 0,3 & Valid \\
\hline & Pernyataan 6 & .634 & 0,3 & Valid \\
\hline & Pernyataan 7 & .634 & 0,3 & Valid \\
\hline & Pernyataan 8 & .882 & 0,3 & Valid \\
\hline & Pernyataan 1 & .639 & 0,3 & Valid \\
\hline & Pernyataan 2 & .882 & 0,3 & Valid \\
\hline & Pernyataan 3 & .637 & 0,3 & Valid \\
\hline Manager & Pernyataan 4 & .882 & 0,3 & Valid \\
\hline (X2) & Pernyataan 5 & .634 & 0,3 & Valid \\
\hline & Pernyataan 6 & .634 & 0,3 & Valid \\
\hline & Pernyataan 7 & .637 & 0,3 & Valid \\
\hline & Pernyataan 8 & .882 & 0,3 & Valid \\
\hline
\end{tabular}

Sumber : Data Diolah, 2019

Tabel 2. Rekapitulasi Hasil Uji Validitas Variabel Laporan Keuangan Berbasis SAK ETAP (Y)

\begin{tabular}{|c|c|c|c|c|}
\hline Dimensi & Butir Pernyataan & R hitung & R kritis & Keterangan \\
\hline & Pernyataan 1 & .634 & 0,3 & Valid \\
\hline & Pernyataan 2 & .882 & 0,3 & Valid \\
\hline & Pernyataan 3 & .637 & 0,3 & Valid \\
\hline & Pernyataan 4 & .882 & 0,3 & Valid \\
\hline Laporan Keuangan Berbasis SAK ETAP & Pernyataan 5 & .634 & 0,3 & Valid \\
\hline$(Y)$ & Pernyataan 6 & .882 & 0,3 & Valid \\
\hline & Pernyataan 7 & .634 & 0,3 & Valid \\
\hline & Pernyataan 8 & .637 & 0,3 & Valid \\
\hline & Pernyataan 9 & 1.000 & 0,3 & Valid \\
\hline
\end{tabular}

Sumber : Data Diolah, 2019

Berdasarkan ketiga tabel di atas, terlihat bahwa seluruh item pernyataan memiliki koefisien validitas yang lebih besar dari r-kritis 0,3 sehingga item-item tersebut layak digunakan sebagai alat ukur dalam penelitian dan dapat digunakan untuk analisis selanjutnya.

Pengujian reliabilitas dilakukan dengan cara menguji coba instrument sekali saja, kemudian dianalisis dengan menggunakan metode Alpha-Cronbach. Kuesioner dikatakan andal apabila koefisien reliabilitas bernilai positif dan lebih besar dari pada 0,7. Adapun hasil dari uji reliabilitas adalah sebagai berikut. 
Tabel 4. Rekapitulasi Hasil Uji Reliabilitas

\begin{tabular}{|c|c|c|c|c|c|}
\hline \multicolumn{6}{|c|}{ Reliability Statistics } \\
\hline \multicolumn{2}{|c|}{ Cronbach's Alpha } & $\mathrm{N}$ of Items & & & \\
\hline \multicolumn{2}{|c|}{.991} & & 3 & & \\
\hline \multicolumn{6}{|c|}{ Item-Total Statistics } \\
\hline & \multicolumn{2}{|c|}{$\begin{array}{l}\text { Scale Mean if } \\
\text { Item Deleted }\end{array}$} & $\begin{array}{c}\text { Scale Variance if } \\
\text { Item Deleted }\end{array}$ & $\begin{array}{l}\text { Corrected Item- } \\
\text { Total Correlation }\end{array}$ & $\begin{array}{c}\text { Cronbach's Alpha } \\
\text { if Item Deleted }\end{array}$ \\
\hline Total_X1 & & 69.42 & 71.334 & .987 & .983 \\
\hline Total_X2 & & 69.32 & 75.981 & .994 & .987 \\
\hline Total_Y & & 61.65 & 58.813 & .996 & .990 \\
\hline
\end{tabular}

Sumber : Data Diolah, 2019

Berdasarkan tabel di atas, diketahui bahwa nilai reliabilitas butir pernyataan pada kuesioner masing-masing variabel yang sedang diteliti lebih besar dari 0,7. Hasil ini menunjukkan bahwa butir-butir peryataan pada kuesioner andal untuk mengukur variabelnya.

\section{Uji Asumsi Klasik}

\section{Hasil Uji Normalitas}

Tabel 5. Hasil Uji Normalitas

One-Sample Kolmogorov-Smirnov Test

\begin{tabular}{|c|c|c|}
\hline & & $\begin{array}{c}\text { Unstandardized } \\
\text { Residual } \\
\end{array}$ \\
\hline $\mathrm{N}$ & & 203 \\
\hline \multirow[t]{2}{*}{ Normal Parameters ${ }^{a, b}$} & Mean & 59,75 \\
\hline & Std. Deviation & 18,733 \\
\hline \multirow[t]{3}{*}{ Most Extreme Differences } & Absolute & .185 \\
\hline & Positive & .084 \\
\hline & Negative & -.185 \\
\hline Test Statistic & & 1,172 \\
\hline Asymp. Sig. (2-tailed) & &, $128^{\mathrm{C}}$ \\
\hline
\end{tabular}

a. Test distribution is Normal.

b. Calculated from data.

c. Lilliefors Significance Correction.

Sumber : Data Diolah, 2019

Karena nilainya di atas 0,05 maka ditribusi data dinyatakan memenuhi asumsi normalitas.

\section{Hasil Uji Heterokedastisitas}

Tabel 6. Hasil Uji Heterokedastisitas 


\begin{tabular}{|c|c|c|c|c|c|c|}
\hline \multicolumn{7}{|c|}{ Coefficients $^{a}$} \\
\hline \multirow{2}{*}{\multicolumn{2}{|c|}{ Model }} & \multicolumn{2}{|c|}{ Unstandardized Coefficients } & \multirow{2}{*}{$\begin{array}{c}\text { Standardized } \\
\text { Coefficients } \\
\text { Beta }\end{array}$} & \multirow[b]{2}{*}{$\mathrm{t}$} & \multirow[b]{2}{*}{ Sig. } \\
\hline & & B & Std. Error & & & \\
\hline \multirow[t]{3}{*}{1} & (Constant) & -.299 & .203 & & -1.472 & .143 \\
\hline & Total_X1 & .293 & .032 & .247 & 4,171 & .125 \\
\hline & Total_X2 & .966 & .034 & .754 & 1,654 & .227 \\
\hline
\end{tabular}

a. Dependent Variable: Total_Y

Sumber : Data Diolah, 2019

Dari hasil uji heterokedastisitas diketahui masing-masing variabel bernilai lebih besar dari 0,05 yang artinya tidak terdapat pengaruh yang signifikan antara variabel independen terhadap nilai absolut residualnya. Dengan demikian, asumsi non heteroskedastisitas model regresi terpenuhi.

\section{Hasil Uji Linieritas}

Tabel 7. Hasil Uji Linieritas

\begin{tabular}{|l|c|c|}
\hline \multicolumn{1}{|c|}{ Model } & Eta & R Square \\
\hline Peranan Ketua Pengurus & 0,503 & 0,384 \\
Manajer Koperasi & 0,541 & 0,457 \\
Pelaporan Berbasis SAK ETAP & 0.535 & 0,311 \\
\hline
\end{tabular}

Sumber : output data diolah, 2019

Berdasarkan tabel diatas menunjukkan bahwa nilai eta $>$ R squared. Dari hasil tersebut dapat disimpulkan bahwa semua variable memiliki hubungan pada linier.

\section{Analisis Regresi Linier Berganda}

Tabel 8. Hasil uji Regresi Linier Berganda

\begin{tabular}{|c|c|c|c|c|c|c|}
\hline \multicolumn{7}{|c|}{ Coefficients $^{a}$} \\
\hline \multirow{2}{*}{\multicolumn{2}{|c|}{ Model }} & \multicolumn{2}{|c|}{ Unstandardized Coefficients } & \multirow{2}{*}{$\begin{array}{l}\text { Standardized } \\
\text { Coefficients } \\
\text { Beta }\end{array}$} & \multirow[b]{2}{*}{$\mathrm{t}$} & \multirow[b]{2}{*}{ Sig. } \\
\hline & & $\mathrm{B}$ & Std. Error & & & \\
\hline \multirow[t]{3}{*}{1} & (Constant) & 4.299 & .203 & & -1.472 & .143 \\
\hline & Total_X1 & .293 & .032 & .247 & 9.187 & .004 \\
\hline & Total_X2 & .375 & .034 & .754 & 28.039 & .103 \\
\hline
\end{tabular}

a. Dependent Variable: Total_Y

Berdasarkan tabel di atas dapat dituliskan persamaan regresi sebagai berikut:

$$
\mathrm{Y}=4,299+0,293 \mathrm{X} 1+0,375 \mathrm{X} 2+\mathrm{e}
$$

Sehingga dapat dijelasakan,

1. Konstanta sebesar 4,299 memiliki arti bahwa jika variabel peranan ketua pengurus dan manajer koperasi bernilai 0 maka penyusunan dan penerapan laporan keuangan berbasis SAK ETAP sebesar 4,299 
2. Koefisien regresi variabel peranan ketua pengurus sebesar 0,293 artinya jika peranan ketua pengurus mengalami peningkatan satu satuan maka penyusunan dan penerapan laporan keuangan berbasis SAK ETAP akan mengalami kenaikan sebesar 0,293 dengan asumsi variabel independen lainnya bernilai tetap.

3. Koefisien regresi variabel manager koperasi sebesar 0,375 artinya jika peranan manager koperasi mengalami kenaikan satu satuan maka penyusunan dan penerapan laporan keuangan berbasis SAK ETAP akan mengalami peningkatan sebesar 0,375 dengan asumsi variabel independen lainnya bernilai tetap.

\section{Uji Hipotesis}

\section{Uji Koefisien Determinasi $\left(R^{2}\right)$}

Tabel 9. Uji Koefisien Determinasi $\mathbf{R}^{2}$

\begin{tabular}{|l|r|r|r|c|}
\hline & & & \multicolumn{1}{|c|}{ Model Summary } \\
Model & $\mathrm{R}$ & $\mathrm{R}$ Square & \multicolumn{1}{c|}{$\begin{array}{c}\text { Squared } \mathrm{R} \\
\text { Square }\end{array}$} & $\begin{array}{c}\text { Std. Error of the } \\
\text { Estimate }\end{array}$ \\
\hline 1 & $.698^{\mathrm{a}}$ & .595 & .695 & 1.327 \\
\hline
\end{tabular}

a. Predictors: (Constant), Total_X2, Total_X1

Berdasarkan Tabel 9 nilai koefisien determinasi $\mathrm{R}^{2}$ terletak pada kolom $R$-square. Diketahui nilai koefisien determinasi sebesar 0,595. Nilai tersebut berarti seluruh variabel bebas secara simultan memengaruhi laporan keuangan berbasis SAK ETAP wajib pajak sebesar 69,5\% sisanya sebesar 30,5\% dipengaruhi oleh faktor-faktor lain.

Uji F

\begin{tabular}{|c|c|c|c|c|c|c|}
\hline \multicolumn{2}{|r|}{ Model } & $\begin{array}{l}\text { Sum of } \\
\text { Squares }\end{array}$ & Df & $\begin{array}{c}\text { Mean } \\
\text { Squares }\end{array}$ & $\mathbf{F}$ & Sig \\
\hline \multirow[t]{3}{*}{1} & Regression & 674.915 & 4 & 168.219 & 41.104 & 0,000 \\
\hline & Residual & 381.835 & 95 & 4.029 & & \\
\hline & Total & 1056.750 & 99 & & & \\
\hline
\end{tabular}

a. Predictors: (Constant), X2, X1

b. Dependent Variable: $Y$

Sumber : Data Diolah, 2019

Tabel di atas menunjukkan nilai Fhitung sebesar 41,104 dengan signifikan nilai Ftabel sebesar 2.47, karena nilai F hitung 41,104 > Ftabel 2,47, maka dapat disimpulkan bahwa Peranan Ketua Pengurus(X1), Manajer Koperasi (X2), berpengaruh secara simultan terhadap terhadap pelaporan keuangan berbasis SAK ETAP

\section{Pembahasan}

Berdasarkan analisis statistik dalam penelitian ini ditemukan bahwa hipotesis diterima yaitu peranan ketua pengurus dan manajer koperasi berpengaruh signifikan positif terhadap pelaporan keuangan berbasis SAK ETAP. Hal ini berarti semakin tinggi peranan ketua pengurus dan manajer koperasi, maka pemahaman pelaporan keuangan berbasis SAK ETAP tentu akan meningkat pula. Hal ini sejalan dengan penelitian Wulanditya dan Supriyati (2012) bahwa Pengalaman Manajer berpengaruh terhadap Penerapan SAK ETAP. Penelitian Minarni \& Sisdiyantoro (2014), mengemukakan bahwa faktor sumber daya manusia berpengaruh positif terhadap implementasi SAK ETAP pada koperasi di Kabupaten Tulungagung. Dang-Duc (2011), menyatakan bahwa 
kurangnya keterampilan manajemen dan akuntansi memiliki dampak negatif pada penyediaan laporan keuangan.

Pengalaman dalam penerapan informasi akuntansi merupakan suatu pembelajaran yang diperoleh manajer dalam menyelenggarakan dan menggunakan informasi akuntansi tersebut. Dang-Duc (2011), menyatakan bahwa kurangnya keterampilan manajemen dan akuntansi memiliki dampak negatif pada penyediaan laporan keuangan.

Ikatan Akuntan Indonesia (IAI) telah menerbitkan Standar Akuntansi keuangan untuk Entitas Tanpa Akuntabilitas Publik (SAK ETAP) pada tanggal 12 Juli 2009 dan berlaku efektif pada 1 Januari 2011. Kehadiran Standar Akuntansi Keuangan Entitas Tanpa Akuntabilitas Publik atau lebih dikenal dengan (SAK ETAP) diharapkan dapat memberikan kemudahan untuk UKM dalam menyajikan laporan keuangan. SAK ETAP juga diharapkan menjadi solusi permasalahan internal koperasi, terutama bagi manajer yang hanya melihat hasil laba yang diperoleh tanpa melihat kondisi keuangan yang sebenarnya.

\section{Kesimpulan}

Peranan Ketua pengurus dan manajer koperasi berpengaruh terhadap pelaporan keuangan berbasis SAK ETAP pada koperasi di Palembang

\section{Saran}

1. Untuk penelitian selanjutnya boleh ditambahkan faktor-faktor lain terkait hubungannya dengan pelaporan keuangan berbasis SAK ETAP.

2. Untuk koperasi sendiri, para ketua dan manajer sebaiknya diikutkan dalam pelatihan pelaporan keuangan berbasis SAK ETAP untuk lebih meningkatkan kualitas pelaporan.

\section{Referensi}

Dang-Duc, S. 2011. Compliance with accounting standards by SMEs in transitional economies: evidence from Vietnam. Journal of Applied Accounting Research, Vol. 12 Iss 2 pp. $96-107$.

Hendar dan Kusnadi. 2009. Ekonomi Koperasi Untuk Perguruan Tinggi Edisi Revisi 2009. Jakarta. Fakultas Ekonomi Universitas Indonesia.

Ikatan Akuntan Indonesia. 2009. Standat Akuntansi Keuangan Entitas Tanpa Akuntabilitas Publik. Jakarta.

Ikatan Akuntan Indonesia. 2011. PSAK 16. Dewan Standar Akuntansi Keuangan. Salemba Empat. Jakarta

Kementerian Negara Koperasi dan UMKM Republik Indonesia 2012. Peraturan Menteri Negara Koperasi dan Usaha Kecil Menengah Republik Indonesia Nomor : 04/PER/M.KUMKM/VII/2012. Tentang Pedoman Umum Akuntansi Koperasi. Jakarta. 25 Juli 2012.

Minarni, E., \& Sisdiyantoro, K. 2014. Faktor-Faktor Yang Mempengaruhi Implementasi Standar Akuntansi Keuangan Entitas Tanpa Akuntabilitas Publik (Studi Empiris 
pada Koperasi di Kabupaten Tulungagung). Jurnal Universitas Tulungagung BONOROWO Vol. 2.No.1 Tahun 2014, xxx-xxx.

Sitio, Harifin dan Halomoan Tamba. 2010. Koperasi Teori dan Praktik. Jakarta : Erlangga.

Sugiyono. 2010. Metode Penelitian Bisnis. Bandung : Alfabeta.

Undang-Undang Dasar Republik Indonesia Tahun 1945 Tentang Koperasi

Undang-Undang Republik Indonesia No. 25 Tahun 1992. Tentang Perkoperasian.

Widiyati, N 2010. Manajemen koperasi. Jakarta.. PT. Asdi Mahasatya.

Wulanditya, P., \& Supriyati. 2012. The SME Perception Towards The Accounting Standard Without Accountability (Sak-Etap) And Self Assessment System For Increasing Voluntary Tax Compliance. International Journal of Business and Management, October 2012. 